\title{
Always reforming? Nurturing a church for human rights in South Africa
}

\author{
Palm, Selina \\ Stellenbosch University \\ spalm@sun.ac.za
}

\begin{abstract}
This article explores the post-apartheid call to South African churches to play an ongoing theological role in the shared task of building a human rights culture for all. It seeks a counter-hegemonic human rights praxis that emphasises the lack of a human rights culture and turns to the early insights of German Reformed theologian Jürgen Moltmann on human rights realisation. This points to an important task for local congregations today. It places this in conversation with current South African empirical realities to argue for a theological disruption of the power-laden imagery underpinning much human rights abuse. It concludes that a liberating Trinitarian praxis for human rights can shape a transformational ecclesiology that speaks to concerns raised by South African church youth within a local church today with a history of struggle involvement. Their voices offer a challenge to churches to be "always reforming" on human rights concerns.
\end{abstract}

Key words

Human rights culture; Jürgen Moltmann; ecclesiology; youth; South Africa

\section{Introduction}

One important contribution of the Reformed faith tradition in particular has been a public theological engagement with human rights concerns, documented by numerous scholars. ${ }^{1}$ Themes of God as involved with and sovereign over all aspects of life have shaped this public engagement. In the South African context, Reformed theologians such as Beyers Naudé,

1 Witte, Johan and Frank Alexander. Christianity and Human Rights: An Introduction (Cambridge: Cambridge University Press, 2010). 
Allan Boesak, John De Gruchy, Dirkie Smit and Nico Koopman have continued this public tradition of human rights engagement. In the 1970s, they explicitly used the language of human rights to decry the abuses of apartheid and to call churches to move from "pious words to action." ${ }^{2}$ The link between justification and justice in the Reformed tradition arguably shapes an ongoing theological commitment to human rights concerns. Despite this heritage however, many South African churches remain primarily absent as role players in building a human rights culture today. Reformed theologian Nicholas Wolterstorff notes an ongoing "troubled" relationship between religion and human rights around the world ${ }^{3}$ while former Anglican Archbishop of Canterbury Rowan Williams suggests there is a "widening gap" between these two discourses with "patterns of crippling mistrust" prevalent between them. ${ }^{4}$

This ambivalent relationship can be traced through South Africa's Christian history ${ }^{5}$ and in 2010, retired Archbishop Tutu noted that "the Christian church should hang its head in shame when it considers the gory and shameful history of the church on human rights." Empirical research by religious scholars points to an ongoing "haze of ambivalence" ${ }^{7}$ in South African churches to human rights post-apartheid, often leading to a lack of action by churches in the task of building a human rights culture. Despite

2 Allan Boesak, "The time for pious words is over: Beyers Naudé, decision, conscience and courage in the struggle for justice," in Mary-Anne Plaatjies-van Huffel and Robert Vosloo (eds.), Reformed Churches in South Africa and the struggle for justice: Remembering 1960-1990 (Stellenbosch: Sun Press, 2013), pp. 213-225.

3 Nicholas Wolterstorff, "The Troubled Relationship between Christians and Human Rights", in Mark. R. Gornik and Greg Thompson (eds.), in Hearing the Call. Liturgy, Justice, Church and World (Grand Rapids: Eerdmans, 2011), pp. 148-155.

4 Rowan Williams, "Reconnecting Human Rights and Religious Faith," in Faith in the Public Square, (London: Bloomsberg Publishing, 2012), pp. 160-175.

5 Selina Palm, "Reimagining the Human? The role of the churches in building a liberatory human rights culture in South Africa today". Unpublished PhD Dissertation 2016. University of Kwa-Zulu Natal. [Online]. Available: http://researchspace.ukzn.ac.za/ handle/10413/13037

6 Desmond Tutu, "To be human is to be free," in John Witte and Frank Alexander (eds.), Christianity and Human Rights: An Introduction (Cambridge: Cambridge University Press, 2010), pp. 1-6.

7 Johannes van der Ven, Jaco Dreyer and Hennie Pieterse, Is there a God of Human Rights: the complex relationship between Human Rights and Religion: A South African Case (Leiden: Brill Publishing, 2004). 
calls for the involvement of all stakeholders by South African legal scholars, ${ }^{8}$ as well as by theologians at the start of the post-apartheid dispensation for church engagement around human rights implementation, ${ }^{9}$ churches often remain absent despite being trusted institutions that engage over $80 \%$ of the population in South Africa. ${ }^{10}$ Human rights leader, Larry Cox, points to religion as the "missing link" in much human rights work today. ${ }^{11}$

This paper suggests that the Reformation challenge to be "always reforming" calls local congregations to a living engagement with a praxis of human rights today to mobilise youth and avoid a mere fossilised commemoration of past struggles. It draws on the theological call to churches around human rights by theologian Jürgen Moltmann in the 1970s as part of the World Alliance of Reformed Churches discussions, formative for South Africa's struggle years.

Churches today may need to reclaim an embodied commitment to what Portuguese scholar Boaventura de Sousa Santos terms a "counter-hegemonic human rights approach"12 that takes sides with the powerless as a core aspect of Christian identity and mission. This is a cruciform approach to human rights to avoid their co-optation to serve existing powers. It draws on empirical research with post-apartheid South African youth ${ }^{13}$ that calls for a "transformational ecclesiology" to shape a church for human rights. It also includes current youth voices from one Reformed congregation that bring fresh voices of challenge to churches to re-find their prophetic voices

8 Sandra Liebenberg. Human Development and Human Rights: South African Country Study. (Oxford University Press, 2000). Laurie Ackermann. Human Dignity: Lodestar for Equality in South Africa. (Cape Town: Juta Law, 2012).

9 Charles Villa-Vicencio. A Theology of Reconstruction, Nation Building and Human Rights. (Cape Town: Cambridge University Press, 1992), p. 45.

10 Steven Rule and Benjamin Mncwango. "Christianity in South Africa: Theory and Practice", in B. Roberts, M. Kivilu and Y. Davies (eds.), in South African Social Attitudes: $2^{\text {nd }}$ report. Reflections on the Age of Hope (Cape Town: HSRC Press, 2010), pp. 185-198.

11 Larry Cox, "Human rights must get religion". 14 th April 2014. [Online]. Available: https:// www.opendemocracy.net/openglobalrights/larry-cox/human-rights-must-get-religion.

12 Boaventura de Sousa Santos, If God were a Human Rights Activist. (Stanford: Stanford University Press, 2015), 1-2.

13 Johannes van der Ven, Jaco Dreyer and Hennie Pieterse. "Is there a Church for Human Rights?” Journal of Empirical Theology 14, no. 2 (2003): 20-52. 
and join what Ethne Regan terms the "struggle for the implementation of human rights ... as signs of our times that cry for justice." ${ }^{14}$

\section{Human rights in South Africa}

In 2016 South Africa celebrated 20 years of its Constitutional Bill of Rights, renowned as one of the most progressive in the world today with an emphasis on judicially enforceable socio-economic rights and the possibility of horizontal application. And yet, despite this milestone, practical realisation of rights remains elusive for many and racialized forms of poverty and inequality remain entrenched. The gap between paper promises and social practices is manifested in the lived realities of the poor despite a strong top-down legal and policy framework for human rights. Abuses of power, sexual violence, and lack of basic services, police brutality and journalistic clamp down are on the rise with 2012 deemed by Human Rights Watch to be South Africa's most concerning year since apartheid. ${ }^{15}$

Despite strong laws, paper policies and political rhetoric in South Africa today, realities for many remain deeply challenging with entrenched systemic inequalities. One in three children born here today is food insecure, nearly 9 million will face child abuse and a rising culture of economic elitism leaves up to $40 \%$ of youth unlikely to ever hold a job. ${ }^{16}$ What do the so-called rights to food, bodily integrity and work really mean in the light of these lived realities which must be the starting point for all critical reflection?

De Sousa Santos suggests that human rights discourse needs to rediscover its counter-hegemonic protest roots if it is to avoid a "complicit promiscuity" between the abstract proclamation of rights for all and passive resignation in the face of its practical violations as merely a hegemonic grammar of depoliticised social change. ${ }^{17}$

14 Ethne Regan, Theology and the Boundary Discourse of Human Rights. (Washington DC: Georgetown University Press, 2010), p. 96.

15 Human Rights Watch Report 2014. South Africa Country Summary. Available at: https:// www.hrw.org/world-report/2014/country-chapters/south-africa.

16 Amnesty International. 2012. "South Africa: Key Human Rights Concerns in South Africa," Amnesty International's Submission to the UN Periodic Review. May-Jun 2012.

17 Santos, If God were a human rights activist, pp. 1-2, 77. 
South African scholars have noted a need to go "beyond the law" 18 to also nurture a human rights culture from below as a shared interdisciplinary task if human rights are to regain their "transformative radicality" today. ${ }^{19}$ Bill of Rights drafter Asmal, noted that "in a country such as South Africa, the development of a culture of human rights is a revolutionary concept." 20

Nevertheless, head of the South African Human Rights Commission, Kayum Ahmed noted in 2012 that "ordinary people do not believe that a culture of human rights has been created here because they see these wonderful rights articulated in our Constitution but at the same time their lived realities do not speak to these rights." ${ }^{21}$ This gap between rights rhetoric and reality resonates painfully in the light of decades of struggle for rights. A human rights culture from below is still needed if paper policies are to become embodied in schools, hospitals, prisons, workplaces, homes and police forces. Empirical research in 2004 suggests that the attitudes and social norms of ordinary citizens sit at the heart of building a human rights culture and that these remain deeply shaped by religious institutions and theologies in South Africa today. ${ }^{22}$

\section{Theologies for human rights?}

Australian Baptist theologian Thorwald Lorenzen ${ }^{23}$ insists that because Christian theology is by its nature public theology, how Christians discern their response to human rights is critical. This contributes towards what South African theologian Christina Landman terms an "embodied public theology" ${ }^{24}$ where human rights are concerned with the bodilessness of

18 Frans Viljoen, (ed). Beyond the Law: Multidisciplinary Perspectives on Human Rights (Pretoria: Pretoria University Law Press, 2012), 3-16. Saul Dubow. The South African Struggle for Human Rights (Cape Town: Jacana Press. 2012), p. 125.

19 Kayum Ahmed, Interview by the International Justice Resource Centre, $12^{\text {th }}$ October 2012. [Online]. Available: http://vimeo.com/51933658 [Accessed: 5 June 2017].

20 Kadar Asmal, "Democracy \& Human Rights: Developing a South African Human Rights Culture," New England Law Review 278 (1992): 1-25.

21 Ahmed, Interview.

22 Van der Ven et al, Is there a God of Human Rights, p. 576.

23 Thorwald Lorenzen. "Freedom from Fear, Human Rights and Christian Faith," Pacifica 19 (2006): 193-212.

24 Christina Landman, "Women Embodying Public Theology" in Christians in Public: Aims, Methodologies and Issues in Public Theology, ed. Len Hansen (Stellenbosch: Sun 
existence and the fragility of bodies. She insists that if religious institutions are to embody human dignity they must begin from the bodily experience of those affected, first giving voice to the voiceless in public spaces and only then "enfleshed" in liturgy, practices and legislation. Human rights sociologist Brian Turner reinforces this interconnection where he notes citizenship discourse requires rights language to grapple fully with issues of dignity and vulnerability, grounding a social ontology of human embodiment that shapes an ethics of hospitality. ${ }^{25}$

Can South African churches help reconnect human rights to new forms of people's theology and citizens' rights so they do not become a legal veneer accessed only by the privileged few? South African realities endorse de Sousa Santos's cry to reconstruct human rights as an emancipatory counter-hegemonic script by drawing on progressive political theologies critical of religious endorsement for existing socio-political patterns. ${ }^{26}$ This offers resources towards developing a decolonised "place-based politics of human rights." 27

This paper will argue that Moltmann's call for theological human rights engagement includes a subversive reimagining of how divine power is understood. This remains relevant in South Africa if a holistic human rights ethos is to be embodied as an imperative with which churches keep faith today, moving from words to action.

Linda Hogan urges religious traditions to reclaim human rights as ethical assertions, an emerging consensus and an emancipatory politics ${ }^{28}$ and points to a need for radical hope in relation to human rights realisation. She asks faith scholars to focus attention not primarily back to the past in a concern with the foundations of human rights discourse but forwards

Press. 2007), pp. 201-208.

25 Brian Turner, Vulnerability and Human Rights. (Philadelphia: Pennsylvania University Press, 2006).

26 Santos, If God were, pp. 45-62.

27 Santos, If God were, p. 77.

28 Linda Hogan, Keeping Faith with Human Rights (Washington DC: Georgetown University Press, 2015). 
towards its future as a task to be accomplished, in need of moral imagination to embed its claims in the hearts and minds of ordinary church goers. ${ }^{29}$

\section{A human rights call to the post-apartheid South African church}

Charles Villa-Vicencio has charted the influential role of religious voices in the historical South African human rights struggle ${ }^{30}$ but also notes that many churches failed to go beyond words into action. Many South African Christians, shaped by centuries of narrow evangelical piety, decried the human rights project as 'of the Devil.' ${ }^{31}$ It was in fact only minority prophetic voices that embodied their faith in relation to concrete human rights practice. In the 1990s, he called for the ongoing engagement of churches in the public sphere in relation to human rights implementation. He made a call to build a liberating and healing culture of human rights as a "revolutionary task" in the new South Africa as an important part of the church's "liberating obligation to society" - a prophetic responsibility in the light of historicised oppression to nurture a praxis for human rights grounded in human personhood. His concern was that if South Africans were not theologically equipped to see human rights as at the centre of human co-existence, rights might become mere decoration or even misused tools that could conceal harsh realities of abuse and exploitation. ${ }^{32}$

Villa-Vicencio was aware of the historical co-optation of much theology to serve power and insisted that the church must remain in solidarity with those who suffer. He stressed that "exploited people should form the norm and not the exception to a human rights agenda." 33 Theology should connect Christians to their traditions to motivate action for human rights as an ethical imperative. However, he argued that in South Africa,

29 Hogan, Keeping Faith, p. 208.

30 Charles Villa-Vicencio. A Theology of Reconstruction, Nation Building and Human Rights. (Cape Town: Cambridge University Press, 1992), p. 45.

31 Charles Villa-Vicencio. 2005. "God, the Devil \& Human Rights: The South African Perspective" in B. Bucar and E. Barnett (eds.), Does Human Rights need God? (Grand Rapids, Michigan: William B Eerdmans), pp. 225-242.

32 Charles Villa-Vicencio, "Christianity and Human Rights". Journal of Law and Religion 14, no. 2 (1999), p. 104.

33 Villa-Vicencio, Theology of Reconstruction, p. 16. 
few churches had made human rights an integrated part of their liturgy, preaching and practice.

In the early $21^{\text {st }}$ century, empirical religious scholars within the Reformed tradition, Van der Ven, Pieterse and Dreyer further interrogated the notion of "a church for human rights" within South Africa by engaging with the voices and religious ideas of 1,453 Grade 11 Christian learners in different schools in Gauteng. ${ }^{34}$ Like Villa-Vicencio, they also pointed soberly to the chequered human rights history of most churches both within their own walls and in wider society to suggest that churches need theological critique from the inside if they are to play an influential role in building a human rights culture. They noted a tri-partite ecclesial landscape on human rights historically in South Africa; theologies that supported apartheid, those that verbally condemned it but became a "paper church", and the confessing or kairos ecclesiastical pressure movements that called for uncompromising solidarity with human right claims and the abolition of apartheid structures as an abuse of human rights. ${ }^{35}$ They called Christianity to help invigorate and inspire a human rights culture, or lose its relevance.

However, their research showed that despite overall positive correlations between the idea of God and human rights, key forms of religious praxis in churches such as Bible reading, religious transfer from parents and religious conviction had a predominantly negative effect on human rights attitudes for youth. ${ }^{36}$ This suggests that church theologies may need transformation if ecclesial attitudes are to be an asset and not a liability in the task of building a human rights culture. In the light of what they see as a broken relationship between much Christianity and human rights, they sketch five contours of a transformational ecclesiology in relation to the ongoing role of the churches in building a human rights culture;

"the main features of a transformational ecclesiology ...

such a church is challenging rather than comforting, strives

for interpenetration rather than isolation, pursues professional competence rather than normative competence, is decentralised

34 Van der Ven et al, "Church for Human Rights," pp. 20-52.

35 Van der Ven et al, "Church for Human Rights," pp. 27-28.

36 Van der Ven et al, Church for Human Rights," p. 83. 
rather than centralised, and cultivates cultural/social openness rather than exclusiveness." ${ }^{37}$

They conclude that South African high school students' ecclesiastical orientations contribute significantly to their human rights attitudes suggesting that a transformational church would have a marked influence. They argue that churches need to establish better rapport with their younger members if they are to nurture a transformational ecclesiology for church renewal.

South African Reformed theologian, Nico Koopman is one scholar who has engaged with human rights post-apartheid, arguing that a faithful public theology has a "liberational agenda that aims to transform the world" in the light of the specific continued gap in South Africa between rhetoric and reality on human rights. ${ }^{38}$ Drawing on Moltmann's influence, Koopman also applies a Trinitarian lens to human rights grounded in a dignifying theological anthropology to call churches into action. ${ }^{39}$ His specific concern in South Africa is with the embodiment of a human rights culture forming, "people who practice what they preach, whose proclaimed and practiced moralities are integrated, people who give content to the human rights that they in theory adhere to ... a place where rights are fulfilled, not infringed, violated or overridden." ${ }^{40} \mathrm{He}$ points out that in the new South Africa millions still experience ongoing violations of their dignity. ${ }^{41}$ Koopman's Trinitarian lens on human rights calls for a shift from theological imperialism to hospitality. ${ }^{42}$ His anthropology of vulnerability and dependence nurtures a solidarity Christology that refuses to associate the imago dei only with perfect humans. Koopman's debt to Moltmann is most clear in his "re-describing God's power in terms of this vulnerability"

37 Van der Ven et al, "Church for Human Rights," p. 40.

38 Nico Koopman, "Some Theological and Anthropological Perspectives on Human Dignity and Human Rights” Scriptura 95 (2007): 177-188.

39 Koopman, “Theological Perspectives”. p. 177.

40 Nico Koopman, “Trinitarian Anthropology, Ubuntu and Human Rights" in Karin Sporre and Russell Botman (eds.), Building a human rights culture: Swedish \& South African perspective, eds. (Falun: Hogskolan Dalarna, 2003), p. 202.

41 Koopman, “Theological Perspectives,” p. 180.

42 Koopman. "Theology and the building of civilizing democracy in South Africa," NGTT 553\&4 (2014): 625-639. 
where human rights offer a "habitat" for the dignity of all, especially the most vulnerable, to flourish as an ubuntu ethic and can challenge distorted power relations. ${ }^{43}$

Where Christians identify with the most vulnerable in the world as a "church under the cross", this gives them their deepest motivation for building a human rights culture. For him, to the extent that South African churches are not eagerly engaged in the struggle for human rights, they are at odds with their core mission. ${ }^{44}$ However, despite his important contributions, Koopman may remain unduly optimistic about South African churches and their current commitment to holistic human rights claims. He suggests (with Smit) that "churches enthusiastically support the Bill of Rights and eagerly monitor real or potential human rights violations". ${ }^{45}$ In reality, church-related organisations such as Freedom of Religion South Africa ${ }^{46}$ who claim to represent 12 million evangelical Christians, have mounted recent challenges against human rights such as gender equality, child protection and sexuality rights ${ }^{47}$ suggesting an ambivalent connection between South African churches and human rights. His focus on powerladen roles such as priests, prophets and kings may unwittingly reinforce problematic notions of civilisation and sovereignty with which these roles are invested and leave certain power hierarchies unchallenged. These androcentric hierarchies can perpetuate humans as passive beneficiaries, supplicants and servants of a divine slave-owner Lord who generates fear and demands unquestioned obedience from 'his' subjects.

It is in search of a counter-hegemonic human rights theology that this paper circles back further in history, where, haunted by the human right abuses of his German historical context and inspired by liberational theologies, Jürgen Moltmann seeks to radically reshape hierarchical God language for structural change around human rights. He may offer spiritual capital

43 Nico Koopman and Dirk Smit, "Public witness in the economic sphere? On human dignity as a theological perspective" in L. Hansen (ed,), Christians in Public: Aims, Methodologies and Issues in Public Theology, (Stellenbosch: Sun Press, 2007), p. 185.

44 Koopman, “Trinitarian Anthropology,” p. 206.

45 Koopman and Smit, "Public witness in the economic sphere?", p. 227.

46 See www.forsa.co.za for various submissions from members that contest human rights.

47 Selina Palm, "Church outrage against smacking aids violence against South Africa's children," The Conversation (14 Jan 2018). 
for South African Reformed churches who still face questions of how to do theology after apartheid, in the light of current oppressions. His words call for constructive local theological engagement in the practical task of building a human rights culture and challenges Reformed theologians need to deconstruct the power-laden categories of their tradition including how God's sovereignty is understood. They also need to grapple with ongoing church complicity in human rights abuses.

\section{Jürgen Moltmann: A Trinitarian praxis for human rights}

According to his biographer, Richard Bauckham, Moltmann's influential early theological contributions to Christian engagement with human rights are at the heart of his theological approach as a concrete outworking of his political theology for churches' relationship to society. ${ }^{48}$ His insistence that human rights engagement must always start from contexts of concrete historical suffering offers an incarnational starting point from below. His concerns emerge from his own German post-war context in the light of theological complicity by most churches in the face of systemic abuse. He offers a radical de/re-construction of God images with concrete implications for socio-political praxis by churches. This situates rights within the relational container of a public, liberating and imaginative theological anthropology $y^{49}$ and a Trinitarian approach to rights grounded in inclusive human dignity and shared vulnerability.

Scottish theologian George Newlands notes that Moltmann offered a unique early starting point for theological engagement with human rights, different from all the other denominational approaches of his day. ${ }^{50} \mathrm{He}$ was aware that in the late 1960s many church congregations saw practical human rights engagement as alien to their core task and in his work for the World Alliance of Reformed Churches over the 1970s, he critically explored "the theological relevance of human rights declarations for

48 R. Bauckham, “Jürgen Moltmann" in D. Ford and R. Myers (eds.), The Modern Theologians ( $3^{\text {rd }}$ ed, Oxford: Blackwell Publishing, 2005, 1995), p. 157.

49 Ton Van Proojen, Limping but Blessed: Jürgen Moltmann's search for a Liberating Anthropology (Amsterdam/New York: Rodophi Press, 2004), p. 173.

50 George Newlands, "Human Rights, Divine Transcendence" in W. Storrer and A. Morton (eds.), Public Theology for the Twenty first century: Essays in honour of Duncan Forrester (London: T\&T Clark, 2004), p. 129. 
Christian practice and the relevance of the socio-political existence of the church for human rights realisation." ${ }^{51}$ Rather than establishing Christian foundations, his interest was to mobilise churches to embody human rights practice as a "revolutionary task," drawing both on his Reformed tradition and on theologies of liberation. ${ }^{52} \mathrm{He}$ was concerned that without a focused intention to overcome existing concrete inequalities, rights declarations could end up "idealistic manifestos without revolutionary significance and even hiding injustice" 53 and insisted on situating human rights within wider struggles for liberation. As an alternative to the prevalent "natural rights" theological model that began from above with a universal ideal of humanity, he offered contours for a Trinitarian praxis for human rights from below.

This begins with an Christological location in a crucified God who takes sides to demand a starting point in the historical particular where the pain is. His social Trinitarian model then emerges as a relational model of being human, grounding human rights commitments in the experience of the praxis of liberation from inhumanity" ${ }^{24}$ where justification by God has social implications for justice to others. Only from this cruciform starting point from below does he then move to the radically democratising intent of the imago dei as a subversive story told within history by slaves to challenge the kings who "lorded" it over others in the monarchical name of a Father God:

"The God of Jesus Christ is not the god of rulers and slaveholders ... but is the God of the humiliated, abandoned battered Jesus, crucified by the Roman occupational forces in the name of the Roman Empire and Roman gods." 55

51 Jürgen Moltmann, “The Original Paper: The Theological Basis of Human Rights and of the Liberation of Human Beings" in Allan Miller (ed.), A Christian Declaration on Human Rights. Theological studies of the World Alliance of Reformed Churches (Grand Rapids: William B Eerdmans, 1977), p. 26.

52 Moltmann, The Original Paper, p. 32.

53 Van Proojen, Limping but Blessed, p. 173.

54 Jürgen Moltmann, On Human Dignity; Political Theology and Ethics. (London: SCM Press, 1984), p. 15.

55 Jürgen Moltmann, "God with the Human Face" in Jürgen Moltmann and Elizabeth Moltmann-Wendel (eds.), Humanity in God (SCM Press, 1983), p. 58. 
He then ties this to the original DNA of the Judeo-Christian story of the creational imperative to locate true human freedom in non-dominating relationships of power-with rather than in top down forms of power-over. ${ }^{56}$ Finally, his eschatological orientation of radical hope then pulls churches forwards into an active anticipatory participation in the building of this future, not as a negation of God's providence but as an affirmation where divine and human freedom coexist. This three-fold, Trinitarian approach to human rights is praxis-oriented and requires a subversive relocation of the divine presence into suffering spaces, not as a power-over humans but as a groundswell of prophetic energy in solidarity with, within and among the "least" and most powerless. As a result, Christians are to re-imagine and participate in bringing into existence a future of social relationships of equal value where the "king-dom" of God is not a monarchy where God dominates, but a community of open friendship with the least.

Moltmann's exodus church exists "particularly for those robbed of human rights and freedoms" and must take sides within history. This hope-inaction inspires a pneumatological ecclesiology ${ }^{57}$ which embodies mutual belonging as a community of equals, calling humans into an active participatory praxis of "anticipating" rather than a passive waiting. ${ }^{58}$ This is related to human rights by the church's messianic task, "in the power of the Spirit" to work for their realisation as a reflection of a world that is coming to be where social life in Christ is reconstituted to reframe questions of class, culture, time and gender. ${ }^{59}$ Hope for Moltmann takes seriously the dynamic possibilities with which all reality is laden and within which Christian identity is lived as a way of existence. The cross first exposes contradictions in our world, and then the Spirit re-embeds humans into their relational responsibilities. ${ }^{60}$

56 Jürgen Moltmann, “The Liberation of Oppressors," Journal of Theology for Southern Africa 26 (1979): 24-37.

57 Kärkkäinen Veli-Matti, Pneumatology. The Holy Spirit in ecumenical contextual and international perspective (Grand Rapids: Baker Academic. 2002), p. 110.

58 Palm, Reimagining the Human, p. 198.

59 Scott Paeth, Exodus Church and Civil Society: Public Theology and Social Theory in the work of Jürgen Moltmann (Farnham: Ashgate Press. 2008), p. 170.

60 Van Proojen, Limping but Blessed, p. 105. 
Moltmann's messianic ethics challenges all utopias of the status quo for the sake of concrete utopias of justice which open up a future where all conditions that destroy human dignity can be negated. But he notes that these future visions remain provisional and require self-critique or human dignity can itself become determined by the strong and exclude the weak. For him, only a messianic order with the suffering of God at its heart can nurture human dignity for all. ${ }^{61}$ His Trinitarian theology connects the groaning Spirit to the crucified God and situates the church in this liminal space. ${ }^{62}$ Eschatological anticipation nurtures historical resistance to enable liberation to enter a world shaped by intersectional oppressions. This concrete reimagining of sin takes note of the historical positionalities of sinners and the sinned against. ${ }^{63}$

According to Van Proojen, Moltmann embeds human rights in the singular concept of human dignity, rejecting an idealistic essentialised anthropology to start instead in the midst of the horrors of history where human beings are still "on the way." ${ }^{4}$ This self is socially situated, understanding freedom not as power-over others but as "becoming together." ${ }^{65}$ In this relational anthropology, oppressors need liberation as well ${ }^{66}$ shifting from the Godlanguage of lordship and servanthood to that of open friendship. Instead of God's sovereignty decentring all human claims to rule, hierarchical power is challenged by relocating God from the apex of the domination pyramid to the bottom, the peripheral places in society and history. This cruciform language for human rights offers a way of (re)imagining the human that troubles our distorted ways of relating to each other and calls the church to embody radically relational alternatives;

"No-one is too great, no one is too small. No one has to look up to anyone...or look down on anyone, Great or small, man or woman,

61 Moltmann, On Human Dignity, p. xiv.

62 Chris Green, "The Crucified God and the Groaning Spirit: Towards a Pentecostal Theology of the Cross in conversation with Jürgen Moltmann," Journal of Pentecostal Theology 19 (2010): 127-142.

63 Moltmann, On Human Dignity, p. 103.

64 Van Proojen, Limping but Blessed.

65 Moltmann and Moltmann-Wendell. "Becoming human in new community" in Humanity in God (London: SCM Press. 1983), pp. 109-126.

66 Moltmann, "Liberation of Oppressors," pp. 24-37. 
black or white, handicapped or non-handicapped, where God is known, the differences disappear and the democracy of the Holy Spirit begins" 67

Moltmann's subversive Trinitarian praxis for human rights offers a theological critique of all images of dominating power that fuel multiple human oppressions. He challenges all churches, and not just those in the 'Reformed' tradition, to relinquish their monarchical, monotheistic, patriarchal God images. These can lead humans to "image" God in ways that reiterate power, mastery, and success and repress vulnerability, suffering and failure in order to legitimate myriad imperial abuses of human power. ${ }^{68}$ Instead his pneumatological ecclesiology destabilises unjust structures to model a relational ecclesiology of friendship and cooperative action not passive obedience and servanthood. ${ }^{69}$ It positions churches in front of society pulling it forwards and transforming traditions, not behind it in the past, resisting change. ${ }^{70}$ It insists that they must challenge all forms of dignity based on the exclusion of others, promote a holistic view of rights and reject its misuse to serve only some, see rights violation as a distortion of the imago dei and sharpen our responsibility to realise the rights of suffering neighbours. Christians operate as a "church for human rights" at multiple levels of wider society. For Moltmann, these are acts of political worship where "Christianity is not only externally and accidentally concerned with human rights but internally, essentially and with the whole of its existence." ${ }^{11}$

Newlands suggests that Moltmann's reinterpretation of Christ as the "instantiation" of a vulnerable God leads to seeing human rights activism

67 Jürgen Moltmann, The Power of the Powerless: The Word of Liberation for Today (London: SCM Press, 1983), p. 46.

68 Moltmann, Becoming Human, pp. 94-95.

69 Joy McDougall, "The Return of Trinitarian Praxis: Moltmann on the Trinity and Christian life," The Journal of Religion 83(2) (2003): 177-203.

70 Jürgen Moltmann, "A Definitive Study Paper: A Christian Declaration on Human Rights" in Allan Miller (ed.), A Christian Declaration on Human Rights. Theological Studies of the World Alliance of Reformed Churches (Grand Rapids: W. B. Eerdmans, 1977), pp. 129-143.

71 Moltmann, “The Definitive Study Paper”, p. 140. 
as a key part of Christian discipleship that many still remain blind to ${ }^{72} \mathrm{His}$ human rights approach, situated within an ethic of liberation, offers two additional "legs" to form a Trinitarian stool, with a location (from below) and orientation (from ahead) grounded in a Christological boundarybreaking narrative of social connection which empowers congregations to "fight against all social structures which degrade human worth." ${ }^{73}$ It is this approach which will be followed back into South Africa.

\section{A transformational ecclesiology - nurturing a church for human rights}

The pneumatological ecclesiology for human rights that guides Moltmann's vision resonates with post-apartheid calls for a transformational ecclesiology emerging from the human rights research in South Africa by Van der Ven et al and their call to engage church youth on this issue. ${ }^{74}$ To embody this, I conclude with a few selected youth voices from one local Reformed congregation, raised as part of research on youth spiritualities for social justice. ${ }^{75}$

Rondebosch United Church (RUC)'s ethos ${ }^{76}$ has been guided for many years by a vision of "Enlarging Circles of Dignity", pointing to the importance of a grassroots theology that takes concrete contexts seriously. It draws on the principles of roundtable worship and a God of dialogue. According to its current minister Robert Steiner, this vision brings together the theological dimensions of life with the socio-political dimensions, connecting spirituality and social justice. Circles of dignity modelled around the roundtable in worship are intended to extend out into everyday

72 George Newlands, Christ and Human Rights: The Transformative Engagement (Minneapolis: Ashgate, 2006), p. 12.

73 Paeth, Exodus Church, p. 15.

74 Van der Ven et al, "Church for Human Rights"

75 All quotations are from interviews with church youth aged 18-24 for a research project at Rondebosch United Church undertaken by Palm at the Unit for Religion and Development Research, Stellenbosch University where ethical clearance was obtained (SU-HSD-004323). Pseudonyms are used for confidentiality. They point towards similar themes as earlier research.

76 Rondebosch United Church emerges from a Congregational tradition and then merged with the Presbyterian Church in recent decades. See www.rondeboschunitedchurch.org.za. 
lives and ministries, both communal and individual. These circles are ones of inclusivity, solidarity, prophetic protest of injustice and compassion. Services seek to rehearse and enact these in ways that have ripple effects into communities with a particular concern for the rights of the weakest in society, those left out, marginalised or exploited". ${ }^{77}$ Members are encouraged to challenge all status quos that perpetuate injustices, drawing on their roots as an anti-apartheid struggle church. According to one youth member; "I feel like a large part of RUC's theology is based on that social justice model - like its stance against apartheid was based on a theology of social injustice and that also shapes its openness in its attitudes to the LGBTQ community"78

RUC seeks to embody a "transformational ecclesiology" for human rights praxis shaped by the contours noted earlier and engaging its youth around spiritualities for social justice. Youth interviewed note that they are proud of RUC's social justice ethos, but that it reflects a significantly different approach to many current human rights concerns than other churches they have encountered. They point to the importance of a moving away from pious rules to a faith that shapes how to live as better human beings together, in a relational anthropology;

"I felt very proud of RUCs ethos - its different values and ways of thinking ...This hit home once when a friend said 'you aren't a real Christian' - she did not see our church as real Christianity with the right rules... RUC goes to the heart of the matter differently by asking how do we live as better human beings not as policed human beings." 79

Themes of judgement, labelling and hypocrisy were noted by youth interviewed critically as common in many other Christian churches and a disincentive for their engagement. They note that they often see exclusive theologies internalised by their Christian peers, shaping their attitudes to others on issues of gender and sexuality rights in particular. In contrast, what draws them to RUC is a strong sense of inclusion and acceptance,

77 Robert Steiner, (RUC minister) personal communication to the author, March 2017.

78 Dan, aged 19, coloured male youth.

79 Angela, white female youth, aged 18. March 2017. 
and a lack of judgement and labelling, which they see as modelled in the services in preaching, songs and liturgies and also in the diverse makeup of the congregation itself, including minority sexualities, former and current prisoners, atheists and homeless people. RUC's theology seeks to challenge not reinforce all hierarchical social judgements of "better than" equipping youth to be critical of theologies which perpetuate racism, sexism, homophobia or disability prejudice.

"What I like about RUC is that we are not judged it does not matter where you come from, or who you are, gender, sexuality, at the end of the day we are all God's creation and children ... You are still accepted. It does not matter if you have a criminal record that is what I have noticed about RUC and it's grown on me. We are all humans and we make mistakes. I know at other churches you will get judged for those mistakes ... You will be outcast or labelled. Labels are a huge problem for me, coming from Burundi with its history of labelling black people and being violent against them ..."

A strong resistance to "labels" as leading to judgement, exclusion, hatred then even conflict was articulated by youth as part of how social identity formation works in their own experience. There was a recognition that babies are not 'born racist' but with a shared humanity that recognises the cry of another. However, the hierarchical labels given by society around gender, sexuality and race were often internalised by youth as a "fictional identity" and reinforced by churches as a form of force-feeding from birth that young people ended up defending rather than challenging. Church was imagined as a place where hierarchical labels could be challenged although many shared other church experiences where the opposite had been true ${ }^{81}$.

The anti-apartheid call by Reformed theologians for churches to go beyond pious words into action remains relevant for the next generation at RUC in relation to ongoing human rights issues especially gender, sexuality and children's rights. They situate themselves within a historical trajectory of youth protest that saw earlier members willing to go to prison and defy

80 Atiemo, black male youth, aged 18. May 2017.

81 Selina Palm, "Re-imagining Sin: Nurturing Youth Spiritualties for Social Justice," in J. Claassens and C. Van der Walt (eds.), Cultivating Change Agents (Stellenbosch: Sun Media, Forthcoming). 
injustices under apartheid. ${ }^{82}$ This suggests that the church seeks to model a lived approach of prophetic challenge for liberation and not merely one of comfort;

"RUC has 'encouraged our 'protest' voices as youth on bigger issues.... I organised a protest for children affected by war held at my school and this action also changed me....I wanted to get people to care about something beyond their comfort zone. Our minister read out my speech in church...it was important for me to move beyond just talking about doing things to doing things" 83

Another arena noted was a commitment by the church and its members to action on issues of justice. This was important to youth who distinguished between charity and the notion of taking shared responsibility for the future and seeking to make changes in the world, inspiring many of them to connect spirituality and social justice and to take action as the below quote notes;

"We are responsible to make change where you think it's due e.g. I notice that [Jane] has always been involved with [a church] project helping children who have to deal with stuff, who are homeless or on their own, you can do something about that, you are free to help out. It's not about feeling sorry, its more that the kids of today are the leaders of tomorrow, we have to raise them to be their own people, to be independent, to see the world for what it really is - to make a change and do some things better - they will be here long after we are gone. It's not about pity, it's about fixing humanity." ${ }^{4}$

Youth noted a problematic theological relationship in many churches to the body. This became particularly apparent in teenage years for girls where their behaviour and dress was policed at many churches. The desire that churches be places where their bodies are respected and affirmed was tied to theology and one young man said, "When I went to 'Church A' as

82 Douglas Bax, "The witness of the Presbyterian Church of Southern Africa 1960-1990" in Mary-Anne Plaatjies-Van Huffel and Robert Vosloo (eds.), Reformed Churches in South Africa and the struggle for justice: Remembering 1960-1990 (Stellenbosch: Sun Press. 2013), pp. 143-170.

83 Angela, March 2017.

84 Atiemo, May 2017. 
a child, I was taught that our bodies don't get to go to heaven because they are too dirty, they are just vessels for the soul, they are not pure but unholy, this makes us feel bad about our bodies."

Finally, notions of power modelled within RUC were commented on positively around church decisions, gender inclusive metaphors for God, involvement of children in the liturgy and the methodology of the Holy Circus, (RUC's Sunday school alternative) where youth are contributory participants, and which also challenges social hierarchies of adults over children.

"I think the hierarchy of power needs to be stripped away in many churches. Here at RUC, the minister, when he wants to implement a plan, we have a meeting and we can talk, it's a democracy, he explains himself and we can see things from different points of view, this is helpful ... it's like we are tied together on the ground and need to help each other to get back up, to work together, one person cannot get up on their own." ${ }^{85}$.

These youth voices point to themes of decentralised power, prophetic protest, social disruption, taking responsibility for change, and nonjudgemental acceptance of diversity that resonate with Van der Ven's five contours of a transformational ecclesiology for human rights and Moltmann's theological disruption of hierarchical power and activist call to churches. They help youth make connections between the treatment of others and their theologies about God.

\section{Conclusion}

What does it mean to take seriously the call to be an "always reforming" church in relation to human rights? Moltmann's exodus church keeps faith with human rights by traveling in solidarity with those who remain crucified today into the future in radical hope. He suggests that if Christian churches are to be part of transforming the imperialisms that underpin many human rights violations, they must also challenge theological imperialisms with open circles of hospitality. This can equip congregations to offer a radical critique of dominating power and to remain prophetic 
and socio-politically relevant by nurturing theological webs of connection to human rights practice. Moltmann's Trinitarian hermeneutic places human rights for the rightless as a theological imperative at the heart of Christian identity and action. His critique of power-laden God images requires theology to 'disrupt' unjust patterns of abuse and domination. A Christology-for-human-rights locates the church on the margins in solidarity with crucified peoples to shape a justified community that reembeds people into just relations.

Unlike some contemporary theologians who speak dismissively of human rights, many South African theologians have engaged publicly with an embodied Trinitarian praxis in relation to building a liberating human rights culture. But it is voices of fear, pain, anger and protest, according to Moltmann, which must remain the starting point for liberating praxis for holistic human rights realisation. A solidarity Christology embraces the broken body of God as the divine protest of all pushed to the margins. It calls churches to practice relational embodiment where their own Body stands on the line with all made vulnerable to build bridges together towards a more just future. This must mobilise a concrete ethic of indignation in the new generation, with human rights abuses seen as blasphemy against the imago dei present in the abused. This needs connection to a hopeful moral imagination for what is possible if local congregations are to become authentic allies in the participatory task of building a people-centred human rights culture from below.

Theological work must shape and be shaped by local church settings. Emerging youth voices here raises important questions as to what churches preach and practice. Unless churches engage with broken realities as the starting point, there is a danger that contemporary voices of lament will remain excluded while angry young activists leave the church. Moltmann's hermeneutical key of the Christ-event turns all human patterns of power upside down and disrupts distorted patterns of relating. If believers' views are shaped around an image of a male violent parent God as a human rights abuser who threatens eternal torture, requires child sacrifice, picks one tribe for genocidal extermination on which the freedom of others is based, models love through passive acceptance of suffering and death, demands unquestioning respect, offers patronage and sends refugees into exile, it is unlikely that Christians will become human rights activists. They are more likely to model patterns of religiously legitimated human rights abuse. 
I end with a set of questions. What "theses" may need to be nailed to church doors in South Africa today in relation to church complicity in human rights abuse and neglect? What might Moltmann's task of becoming human together mean if churches are to take seriously cruciform solidarity with all who suffer concrete human rights violations as an act of located witness? Can churches embody "hope-full" visions of relational freedom with God and others and find ways to pass on a prophetic history for human rights? Are human rights embraced by churches as holistic, interdependent and grounded in forms of egalitarian dignity?

Do theologies proclaimed from pulpits equip congregants to stand up for the rights of others as participation in God's missional task? Can churches take a confessing journey inwards to challenge forms of theological power that remain authoritarian? Are they willing to unlearn theological justifications for social, economic, religious and ecological hierarchies that legitimate abuses? Can political worship become re-centred on the powerless, building emancipatory ecclesial practices of table fellowship, song, story, prayer and liturgy as central to lived witness? Only in engaging these questions together can we become exodus churches for human rights.

\section{Bibliography}

Ackermann. Laurie. Human Dignity: Lodestar for Equality in South Africa. Cape Town: Juta Law, 2012.

Ahmed, Kayum. Interview by the International Justice Resource Centre, $12^{\text {th }}$ October 2012. [Online]. Available: http://vimeo.com/51933658.

Amnesty International. "South Africa: Key Human Rights Concerns in South Africa," Amnesty International's Submission to the UN Periodic Review. May-Jun 2012.

Asmal, Kadar. "Democracy \& Human Rights: Developing a South African Human Rights Culture”. 27 New England Law Review 278 (1992), $1-25$.

Bauckham, Richard. “Jürgen Moltmann.” In The Modern Theologians. (eds) D Ford and R. Myers, R., (147-162. London: Blackwell Publishing, 2005. 
Bax, Douglas "The witness of the Presbyterian Church of Southern Africa 1960-1990" in Reformed Churches in South Africa and the struggle for justice: Remembering 1960-1990, ed. Mary-Anne Plaatjies-Van Huffel and Robert Vosloo. (Stellenbosch: Sun Press, 2013), 143-170.

Boesak, Allan. "The time for pious words is over: Beyers Naudé, decision, conscience and courage in the struggle for justice." In Reformed Churches in South Africa and the struggle for justice: Remembering 1960-1990, ed. Mary-Anne Plaatjies-Van Huffel and Robert Vosloo 213-225. Stellenbosch: Sun Press, 2013.

Cox, Larry “Human rights must get religion". 14 ${ }^{\text {th }}$ April 2014. Open Democracy. [Online]. Available: https://www.opendemocracy.net/ openglobalrights/larry-cox/human-rights-must-get-religion

De Sousa Santos, Boaventura. If God were a Human Rights Activist. Stanford: Stanford University Press, 2015.

Dubow, Saul. The South African Struggle for Human Rights. Cape Town: Jacana Press, 2012.

Liebenberg, Sandra. Human Development and Human Rights: South African Country Study. Cape Town: Oxford University Press, 2000.

Green, Chris. "The Crucified God and the Groaning Spirit: Towards a Pentecostal theology of the Cross in conversation with Jürgen Moltmann". Journal of Pentecostal Theology 19 (2010): 127-142.

Hogan, Linda. Keeping Faith with Human Rights. Washington DC: Georgetown University Press, 2015.

Kärkkäinen. Veli-Matti, Pneumatology. The Holy Spirit in ecumenical contextual and international perspective. Grand Rapids: Baker Academic, 2002.

Koopman, Nico. "Some Theological and Anthropological Perspectives on Human Dignity and Human Rights.” Scriptura 95 (2007): 177-188.

Koopman, Nico. "Trinitarian Anthropology, Ubuntu and Human Rights." In Building a human rights culture: Swedish \& South African Perspectives (eds.) by Karin Sporre and Russell Botman. Falun: Hogskolan Dalarna, 2003). 
Koopman, Nico. "Theology and the building of civilising democracy in South Africa.” In NGTT 553 \& 4 (2014): 625-639.

Koopman, N, and Smit, D. 2007. "Public witness in the economic sphere? On human dignity as a theological perspective." In Christians in Public: Aims, Methodologies and Issues in Public Theology, (ed.) Hansen, L., 269-280. Stellenbosch. Sun Press.

Lorenzen, Thorwald. "Freedom from Fear, Human Rights and Christian Faith.” Pacifica 19 (2006) 193-212.

Landman, Christina "Women Embodying Public Theology" In Christians in Public: Aims, Methodologies and Issues in Public Theology, (ed.) Len Hansen, 201-208. Stellenbosch. Sun Press, 2007.

McDougall, Joy. "The Return of Trinitarian Praxis: Moltmann on the Trinity and Christian life." The Journal of Religion 83(2) (2003):177203.

Moltmann, Jürgen. “The Original Paper: The Theological Basis of Human Rights and of the Liberation of Human Beings". In A Christian Declaration on Human Rights. Theological studies of the World Alliance of Reformed Churches, edited by Allan Miller. Grand Rapids: William B Eerdmans, 1977.

Moltmann, Jürgen and Moltmann-Wendell, Elizabeth. "Becoming human in new community." In Humanity in God. 109-126. London: SCM Press, 1983.

Moltmann, Jürgen. The Power of the Powerless: The Word of Liberation for Today. London: SCM Press, 1983.

Moltmann, Jürgen. "God with the Human Face." In Humanity in God, eds. Jürgen Moltmann and Elizabeth Moltmann-Wendel, 58. London: SCM Press, 1983.

Moltmann, Jürgen. "A Definitive Study Paper: A Christian Declaration on Human Rights." In A Christian Declaration on Human Rights. Theological Studies of the World Alliance of Reformed Churches, edited by Allan Miller, 129-143. Grand Rapids: W. B Eerdmans, 1977. 
Newlands, George. "Human Rights, Divine Transcendence” In Public Theology for the Twenty first century: Essays in honour of Duncan Forrester, edited by W Storrer and A Morton. London: T\&T Clark, 2004.

Newlands, George. Christ and Human Rights: The Transformative Engagement. Minneapolis: Ashgate, 2006.

Paeth, Scott. Exodus Church and Civil Society: Public Theology and Social Theory in the work of Jürgen Moltmann. Farnham: Ashgate Press, 2008.

Palm, Selina. "Reimagining the Human? The role of the churches in building a liberatory human rights culture in South Africa today". Unpublished PhD Dissertation. 2016. [Online]. Available: http:// researchspace.ukzn.ac.za/handle/10413/13037

Palm, Selina. "Church outrage against smacking aids violence against South Africa's children”. The Conversation. [Online]. Available: https:// theconversation.com/church-outrage-over-spanking-ban-aids-violence-against-southafricas-children-88098. [Accessed: 14 Jan 2018].

Palm, Selina. "Re-imagining Sin: Nurturing Youth Spiritualities for Social Justice". In Cultivating Change Agents, edited by J Claassens \& C Van der Walt. Stellenbosch: Sun Media, 2018.

Regan, Ethne. Theology and the Boundary Discourse of Human Rights. Washington DC: Georgetown University Press, 2010.

Rule, Steven and Mncwango, Benjamin. "Christianity in South Africa: Theory and Practice". In South African Social Attitudes: $2^{\text {nd }}$ report. Reflections on the Age of Hope. Edited by B Roberts, M Kivilu and Y Davies, 185-198. Cape Town: HSRC Press, 2010.

Turner, Brian. Vulnerability and Human Rights. Philadelphia:

Pennsylvania University Press, 2006.

Tutu, Desmond. “To be human is to be free." In Christianity and Human Rights: An Introduction, eds. John Witte and Frank Alexander, 1-6. Cambridge: Cambridge University Press, 2010. 
Van der Ven, Johannes. Dreyer, Jaco, and Pieterse. Hennie. Is there a God of Human Rights: the complex relationship between Human Rights and Religion: A South African Case. Leiden: Brill Publishing, 2004.

Van der Ven, J, Dreyer, J and Pieterse, H. "Is there a Church for Human Rights?” Journal of Empirical Theology 14(2) (2003):20-52.

Viljoen, Frans (ed). Beyond the Law: Multidisciplinary Perspectives on Human Rights. Pretoria: Pretoria University Law Press, 2012.

Villa-Vicencio, Charles. A Theology of Reconstruction, Nation Building and Human Rights. Cape Town: Cambridge University Press, 1992.

Villa-Vicencio, Charles. "Christianity and Human Rights." Journal of Law and Religion 14(2) (1999): 579-600.

Villa-Vicencio, Charles. "God, the Devil \& Human Rights: The South African Perspective". In Does Human Rights need God? edited by B Bucar \& E Barnett, 225-242. Grand Rapids, Michigan: William B Eerdmans, 2005.

Williams, Rowan. "Reconnecting Human Rights and Religious Faith." In Faith in the Public Square, edited by Rowan Williams, 160-175. London: Bloomsberg Publishing, 2012.

Witte, John and Alexander. Frank. Christianity and Human Rights: An Introduction. Cambridge: Cambridge University Press, 2010.

Wolterstorff, Nicholas. "The Troubled Relationship between Christians and Human Rights." In Hearing the Call. Liturgy, Justice, Church and World, edited by Nicholas Wolterstorff 148-155. Grand Rapids: Eerdmans, 2011. 